\title{
Serbia's relations with its Western Balkan neighbours as a challenge for its accession to the EU
}

\author{
Milenko Petrovic \\ University of Canterbury \\ milenko.petrovic@canterbury.ac.nz \\ Garth Wilson \\ University of Canterbury \\ garth.wilson@canterbury.ac.nz
}

\begin{abstract}
Serbia, as the second regional frontrunner (after Montenegro) in the EU accession process, hopes to be able to meet the required conditions and join the EU by 2025 which the European Commission 2018 enlargement strategy declared as the earliest possible date for the admission of new EU members. However, some of the EU's expectations and requirements which Serbia has to meet, particularly those regarding the 'normalisation' of its relations with Kosovo and the resolution of 'bilateral disputes' which it has with some other neighbours, seem to be very tough and challenging for the Serbian government. The article discusses the recent developments in Serbia's relations with its 'most problematic' neighbours and critically assesses the strength of problems in these relations as an obstacle for Serbia's accession to the EU. The article shows that thanks to EU assistance and the commitment of interested parties to find a common ground, Serbia's relations with Kosovo may become even less of an obstacle to its accession than its relations with its three western neighbours, particularly Croatia.
\end{abstract}

Keywords: Serbia's accession, neighbourhood relations, problems, Kosovo, Bosnia and Herzegovina, Croatia, Montenegro

There are obvious differences in the quality of political relations that successive governments of post-Milosevic Serbia have been able to establish and maintain with Serbia's regional neighbours over the last two decades. While general political (and socio-economic) relations between Serbia and all of its neighbours to the north and east - Hungary, Romania and Bulgaria - and with post-Yugoslav Macedonia ${ }^{1}$ to the south can be assessed as good (or even very good) with no open issues and problems, ${ }^{2}$ quite the opposite can be said for the country's relations with its remaining neighbours.

\footnotetext{
${ }^{1}$ It is solely for reasons of clarity, and without any attempt to connect on the nearly thirty year long 'name debate' with Greece (which seems to be finally concluding at the time of writing in September 2018) that this country is referred to as 'Macedonia' in this paper and not the Former Yugoslav Republic of Macedonia (FYRM) which is (still) in official use by the UN, international organisations and those states which accept Greek argument in this debate (for more detail on this debate see e.g. Geddes and Taylor, 2016 and Tzallas, 2018).

${ }^{2}$ At particular occasions the question of the status of the Hungarian or Romanian ethnic minorities in Serbia has been raised by some politicians (less so governments). However it has never posed a serious problem in Serbia's relations with either of these countries in the last two decades (see e.g. comment in Markovic's contribution to this issue regarding Romania's complaints about the treatment of the Vlach/Romanian minority in Serbia).
} 
Although they have generally improved over the period since the end of the civil wars in Croatia and Bosnia and Herzegovina (B-H) in 1995, and particularly since the early 2000 s and the 'second' democratisation of Croatia and Serbia, 3 Serbia's bilateral relations with its neighbours to the west (Croatia, Bosnia and Herzegovina and Montenegro) and particularly south-west (Kosovo) are still fragile and subject to various challenges. Mainly rooted in the legacy of the violent dissolution of Yugoslavia, particularly the different interpretations of the causes of the ethnic conflicts in Croatia, B-H and Kosovo and their scope and consequences (see e.g. Cohen, 1995; Lampe, 1996; Woodward, 1995) problems in relations with these neighbours are of significant importance with respect to both Serbia's general political security and stability, and as a condition for its accession to the EU.

While the EU clearly stated when Serbia was granted candidate status for membership in March 2012, that the cornerstone of its accession would be the 'normalisation' of its (officially not existing) relations with Kosovo and its "commitment and progress ... in the [EU facilitated] Belgrade-Pristina dialogue" (EU General Affairs Council, 2012, p. 1), Serbia's problems with its three western neighbours are also an important part of its accession agenda. Somewhat paradoxically, thanks to some progress made in the 'Belgrade-Pristina dialogue,' Serbia's relations with Kosovo may become even less of an obstacle to its EU accession than its relations with its three western neighbours. Despite formally established diplomatic relations with Croatia, B-H and Montenegro, Serbia's relations with these three successor states of former Yugoslavia can be characterised as more 'problematic' or 'difficult' than normal. Particularly worrying are the perpetually difficult relations between Serbia's political elite and the political leaders of the ethnic Bosniaks in B-H and the significant worsening of bilateral relations between Serbia and Croatia in recent years.

Although primarily resulting from the interplay of domestic factors which are addressed in greater detail in the next section, this can also be seen as an outcome (or 'by-product') of the EU's prioritisation of policies which have targeted short-term political stability and security in its neighbourhring countries by relying on (and often contributing to the rise of) non-democratic political practices and authoritarian leaders rather than consolidation of democracy in these countries (Bieber, 2018; Juncos and Whitman, 2015; Pomorska and Noutcheva, 2017; Kovacevic, this issue). As the latter is closely accompanied by populism, nationalism and the increased animosities towards the other ethnic groups, all of which has characterised relations between Serbia and its three western neighbours over the last decade, the EU's safe-guard 'security approach' can also be considered a contributing factor to the troublesome state of these relations. Its involvement and partial responsibility did not, however, prevent the EU from asking Serbia and their Western Balkan neighbours to 'clean up their mess' and, as outlined in the 'Enlargement strategy' of February 2018 to solve all their 'bilateral disputes ... as a matter of urgency' (European Commission 2018a, p. 7) if they want to advance towards EU membership. This may appear to be particularly demanding for Serbia and its accession bid not only on account of the 'Kosovo issue'.

After providing an overview and critical assessment of the current state of play in Serbia's relations with Kosovo (in Section 1) and the three other above mentioned post-

\footnotetext{
${ }^{3}$ After the death of Croatia's authoritarian president Tudjman in December 1999 and the overthrow of Serbia's postcommunist dictator Milošević in October the following year.
} 
Yugoslav states, this article evaluates the strength of these problems as an obstacle for Serbia's accession to the EU in the final section.

\section{Serbia and Kosovo}

Although it may be argued that moderate progress has been achieved in relations between Kosovo and Serbia over the years that followed the launch of the EU facilitated 'Belgrade-Pristina dialogue' in Brussels in 2011, and particularly following the adoption of the Brussels Agreement in April 2013,4 official relations between Serbia and Kosovo are still non-existent. Ten years since the biggest world powers in the West (USA, Germany, France, Italy and the UK) decided to recognise Kosovo's independence and asked other countries in the world to follow suit, Serbia continues to refuse to do so and finds support for this among the two non-western members of the UN Security Council - Russia and China - and over 80 members of the UN (including five member states of the EU) who have not yet recognised the independence of this former province of communist Serbia. Despite Serbia's positive response to the EU's request (or more precisely 'ultimatum') to either improve relations with the Kosovo government (run almost exclusively by ethnic Albanians who comprise over 90 per cent of Kosovo's population) or to 'forget' about its accession to the EU and its acceptance to open the above mentioned 'Dialogue' with the government in Pristina in 2011,5 the relationship between the two parties remains very tense. Although the parties agreed at the Brussels talks to establish some official communication, ${ }^{6}$ this is mainly conducted via the EU's and UN civil and military missions in Kosovo ${ }^{7}$ and has been marked with frequent incidents, some of which (as illustrated below) were on the brink of inciting an open and violent crisis. Moreover, the very interpretation of the obligations of the two parties regarding the implementation of the Agreement provides a new source of disputes between them.

While consecutive Serbian governments have until very recently presented the adoption of the Brussels Agreement as a 'great victory' of Serbian diplomacy, which was able to secure written and internationally recognised (by virtue of the fact that it was adopted under EU sponsorship) guarantees for the political autonomy of the Serbian ethnic minority in Kosovo, the vague content and 'semi-official' character of the agreement (Crisis Group, 2013) have in fact 'guaranteed' very little. Particularly the implementation of the first six (of 15) short points of the agreement which regulate the most important concession for the Serbian side: the establishment and functioning of an "Association/Community of Serb majority municipalities in Kosovo" has become

\footnotetext{
${ }^{4}$ It is interesting that it was only initialled and never signed by the two prime ministers (see e.g. Crisis Group, 2013). The agreement in full is available at: http://www.kryeministriks.net/repository/docs/FIRST_AGREEMENT_OF_PRINCIPLES_GOVERNING_THE_NORMALIZATION_OF_RELATIONS,_APRIL_19,_201 3_BRUSSELS_en.pdf.

${ }^{5}$ When the European Council in December 2011 decided not to follow (for the first time in the history of the EU's eastern enlargement) the recommendation of the European Commission to grant official candidate status to an applicant country, the only reason was Serbia's unsatisfactory progress 'in the Belgrade-Pristina dialogue". Again, after Serbia had "improved itself" and had "show[n] credible commitment and achieved further progress in...the Belgrade-Pristina dialogue; (EU General Affair Council, 2012. p. 1) it was granted official candidate status at the next European Council in March 2012.

${ }^{6}$ Kosovo and Serbia have agreed to exchange liaison officers although their assigned role is highly ambiguous (Barlovac, 2013).

${ }^{7}$ The United Nations Interim Administration Mission in Kosovo (UNMIK) established by Security Council resolution 1244 for ensuring peace and security after the NATO intervention against the Milosevic regime (bombing of Serbia and Montenegro) was terminated in June 1999 and the European Union Rule of Law Mission (EULEX) was established in 2008 for supporting and supervising the work of Kosovo police and legal institutions (for more details see Fakiolas and Tzifakis, 2017 and Petrovic, 2017).
} 
problematic. While the Kosovo government and even more so the nationalist opposition have from the very beginning been very reluctant to implement this part of the Agreement, the Kosovo Constitutional Court declared in 2015 that all (vital) parts of the Agreement which grant autonomous executive rights to the Association of Serb municipalities "are not entirely in compliance with the spirit of the [Kosovo] constitution" and that the Association should be established taking this into account (Deutsche Welle, 2015). Although the other parts of the Agreement, particularly those which regulate the incorporation of the Serbian Police forces and the judicial system in Serb dominated northern Kosovo into integrated Kosovo structures (points 7-10) ${ }^{8}$ as well as point 14 which is the only one 'explicitly about bilateral relations' (Crisis Group, 2013) ${ }^{9}$ have so far been more or less fully implemented, the unresolved formal status of the three Serb controlled municipalities in Northern Kosovo ${ }^{10}$ has remained a 'regular source' of accusations and counter-accusations between the two parties.

Since the Brussels talks effectively stalled in 2016 due to the above outlined request from the Kosovo Albanian side for the revision of the first part of the Brussels agreement and Serbia's strong rejection of it, tensions and nationalist rhetoric have seriously increased and have been evident in numerous incidents. Among these, especially inflammatory were the arrest of the high-ranked Kosovo politician, former and current Prime Minister Haradinaj in France on 4 January 2017 (based on Serbia's arrest warrant for alleged war crimes) that was followed by the adoption of the Kosovo Parliament resolution that demanded the suspension of the Brussels talks until he was released (Emini and Stakic, 2018). ${ }^{11}$ The departure of a 'Kosovo is Serbia' train from Belgrade for north Mitrovica in north Kosovo only two days after Haradinaj was released from the French prison is also noteworthy. Eventually the train, whose carriages were painted in the colours of the Serbian national flag and the message 'Kosovo is Serbia' in 21 different languages was stopped by the 'direct order' of Prime Minister Vučić before it reached the Kosovo border (Morina, 2017). All three events enormously increased tensions between the two parties. The tensions again reached boiling point in early 2018 with the (still unresolved) assassination of the independent Serb politician Oliver Ivanovic in North Mitrovica on 16 January for which both sides have been accusing each other (Ciric, 2018; Emini and Stakic, 2018) and with the theatrical arrest and quick release (dramatically reported in the media) of the head of the Serbian Government office for Kosovo, Marko Djurić in the same city on 26 March during his non-authorised (by the Kosovo government's interpretation) visit to north Kosovo. ${ }^{12}$ More recently, in early August 2018 Serbian President Vučić called an 'urgent' meeting of the national Security Council and wrote an open letter to Kosovo Serbs to assure them that although Kosovo Albanians will 'not lift a finger to establish the promised Association of Serb Majority Municipalities in Kosovo ... Serbia is ready

\footnotetext{
${ }^{8}$ Subject to the condition that these would continue to be run by Kosovo Serbs (as specified in points 9 and 10 of the Agreement).

${ }^{9}$ It states that 'neither side will block ... the other side's progress in their respective EU paths'.

${ }^{10}$ The Brussels Agreement has in fact helped the Serbian government (as it was in this regard supported and assisted by both the Kosovo government and the EU/international actors) to put under its ultimate control all the so called 'parallel institutions' in northern Kosovo and eliminate all alternative (and genuinely) autonomous political options and organisations of Kosovo Serbs (see e.g. Emini and Stakic, 2018).

${ }^{11}$ Although he was quickly released from prison (on 12 January) he was not allowed to leave France until the court made a decision regarding his requested extradition to Serbia. The request was finally rejected on 27 April 2017 when Haradinaj was allowed to leave to Kosovo which sparked outrage in Serbia where then Prime Minister (and current President) Aleksandar Vučić called the ruling 'a great victory for criminals' (Radio Free Europe, 2017).

${ }^{12}$ One of the agreed issues at the Brussels talks which were not included in the 2013 Agreement was the procedure governing the visits of Serbia's officials to Serbian enclaves in north (and other areas of) Kosovo which however was also differently interpreted by the two parties (see e.g. The Guardian, 2018a and Telegraf, 2018).
} 
to fulfil its obligation to [them] and protect [their] lives and [their] peace, if necessary' (Deutsche Welle, 2018b; Rudic, 2018).

However, it seems that the main purpose of all of these incidents and even more so the ultra-nationalist rhetoric which accompanied them was, particularly on the Serbian side, set the scene for a more robust governmental attempt to find a lasting 'compromise solution' for the Kosovo 'knot' which would be 'not easy and painless' (for the wider Serbian public) as Vučić stated just a few days after he sent the above letter to Kosovo Serbs (B92net, 2018). In trying to find a 'compromise' by which Serbia would get 'something concrete in return' for de facto (or de jure) recognition of Kosovo's independence (Walker, 2018) through signing the 'legally binding agreement' with Kosovo requested by the EU (European Commission, 2018b; see also the Introduction to this issue) Vučić has used strong 'anti-Kosovo' rhetoric in an attempt to weaken the opposition that his 'compromise' has received from the (ultra) nationalist political parties and some intellectual circles in Serbia. Particularly problematic for him in this respect is the firm rejection of any 'idea' of a 'separation of Kosovo from Serbia' that has come from the high authorities of the influential Serbian Orthodox Church (see e.g. B92net/Tanjug, 2018a and Blic, 2018). Nevertheless, Vučić's 'compromise solution', whose main points (as recently unveiled) are the alteration of current borders between Kosovo and Serbia (Gotev, 2017; Politico, Aug 2018;) 13 and securement of an exterritorial status for the Serbian monasteries in Kosovo (and perhaps some limited, mainly cultural autonomy for a few Serbian enclaves which will remain in Kosovo) is strongly supported by the party base of Vučić's own Serbian Progressive Party (SPP) and its main partner in the ruling coalition - the Socialist Party of Serbia (SPS) ${ }^{14}$ and some other smaller parties and NGOs in the domestic political scene. Furthermore it has also started to 'gain momentum' at the international scene in recent months and weeks. While Kosovo's President Thachi has sent signals about his readiness to consider it, the above outlined 'compromise' has also been positively perceived by the main EU representatives in the Brussels talk and by the current US administration which has been one of the major and most influential international supporters of Kosovo independence (Politico, 2018; Rettman, 2018). However, while Thachi faces very strong domestic opposition in this regard, the leaders of other influential international players and EU member states, particularly the UK and Germany, have so far also been reluctant to consider any deal between the two parties which would include a 'redraw of borders' that could be taken as precedent for other states with similar issues (Rettman, 2018).

Nevertheless at the August (2018) talks in Vienna between Vučić and Thachi which were organised by the Austrian government (which holds the EU Presidency until the end of 2018) and the EU's Commissioner for European Neighbourhood Policy and Enlargement, Hahn, all actors involved - the two Balkan Presidents and their EU hosts - expressed optimism regarding the possibility of reaching a mutually acceptable compromise (Viena.At, 2018; Politico, 2018). Time will show whether this optimism will indeed lead to an early resolution of the 'Kosovo knot' and a less problematic Serbia-Kosovo relationship.

\footnotetext{
${ }^{13}$ By which three Serb municipalities in north Kosovo will be swapped for one Albanian dominantly populated municipality in southern Serbia.

${ }^{14}$ Its leader, current Deputy Prime Minister and Foreign Minister Dacic was indeed the first high ranked Serbian official who publicly announced the idea of 'delimitation' as a possible solution of the Kosovo-Serbia problem (Gotev, 2017).
} 


\section{Serbia and its post-Yugoslav neighbours to the west}

If there is reason for being cautiously optimistic in viewing the prospect of resolving the Kosovo challenge to Serbia's accession within the short to medium term, recent developments and trends in Serbia's relations with its three western neighbours do not seem as promising. Although the character of these relations is definitely less challenging for Serbia's EU ambitions than that with Kosovo, the fact that the EU recently adopted the above mentioned additional accession condition that the Western Balkan candidates for EU membership must solve their 'bilateral disputes ... as a matter of urgency,' and that Serbia currently has many such disputes with its three western neighbours may also pose a serious obstacle on its way to EU membership. This is particularly noteworthy with regard to Serbia's continuously worsening relations and increasing (instead of, as could be expected decreasing) number of disputes on various issues with Croatia, which is an EU member state and as such able to block or at least slow down progress in Serbia's accession negotiations. As will be shown below, Croatia's officials and political representatives have not hesitated to make such attempts on several occasions so far.

\section{Montenegro}

Although they have not been cordial since the time when the Montenegrin political leader and Prime Minister Djukanovic refused to obey Serbian ruler Milosevic (then the president of 'smaller' Yugoslavia which comprised only Serbia and Montenegro) in the late 1990s, 15 relations between Serbia and Montenegrin officials worsened considerably in the early 2000 s when the Djukanovic government largely boycotted the work of (a few) central institutions of the 'State Community of Serbia and Montenegro' established by the EU sponsored agreement in 2002. ${ }^{16}$ Being only genuinely interested in full separation from Serbia and the re-establishment of 'Montenegrin statehood,' Djukanovic was not interested in any serious cooperation with the pro-reform and pro-EU ruling political elite in post-Milosevic Serbia, and was only waiting for the three required years (as defined by the establishing agreement of the 'state community') to pass before he could call a referendum for Montenegro's independence (Massari, 2005; Petrovic, 2013). Since the Djukanovic proindependence bloc scored a narrow victory in the 2006 referendum, the country has remained sharply divided between the 'separatist' or 'Montenegrin' Djukanović led ruling coalition, and the mainly 'unionist' and proSerbian opposition which have unsuccessfully been trying to remove Djukanović from power (Džankić, 2014). ${ }^{17}$

\footnotetext{
${ }^{15}$ In addition to ignoring Milosevic's instructions regarding Montenegrin internal affairs, he also separated Montenegro's economy from the Yugoslav central bank and, with Germany's blessing, introduced the Deutsche mark in 1999 (and from 2002 the euro) to be the Montenegrin currency (see e.g. Deutche Welle, 2013 for more details).

${ }^{16}$ The agreement for the foundation of the common state titled 'state community,' which had a common Army and common foreign policy as de facto the only genuine common institutions) was signed under the presence and supervision of the European Union High Representative for CFSP Javier Solana on 14 March 2002 and subsequently adopted by the parliaments of both republics and the federal parliament on 4 February 2003 as "The Constitutional Charter of the State Community of Serbia and Montenegro" (see Petrovic, 2013 for more details).

${ }^{17}$ Montenegro is the only post-communist state in Europe which has never experienced an electoral change of ruling party or leader. The Democratic Party of Montenegrin Socialists (formerly the League of Montenegrin Communists) and its leader, Milo Djukanovic have been in power throughout the whole period of post-communist (and even the last few years of communist) history of the country. Djukanović himself has served six terms as prime minister and two as president of the country during this period. He is the current President of the country, elected in the election held on 18 May 2018 (for more details about his rule see e.g. Deutsche Welle, 2018a; Hopkins, 2012; Tomovic, 2016a and Vachudova, 2014).
} 
The Serbian government immediately accepted the results of the referendum (despite the very narrow results and numerous complaints about the irregularity of the referendum process launched by the defeated unionist bloc ${ }^{18}$ ), and recognised Montenegro's independence twelve days after it was officially declared on 3 June 2006 (Canas, 2007). Nevertheless, divisions between 'separatists' and 'unionists', alongside the status of the Serbian Orthodox Church in Montenegro, ${ }^{19}$ have remained the largest source of problems in relations between the two countries following their peaceful separation. On several occasions domestic political developments have directly affected (or at least threatened to affect) Montenegro's (i.e. Djukanović's) relations with Serbia's officials. The most recent incident occurred on the very day of the last Montenegrin parliamentary election held on 16 October 2016 when the news broke that the Montenegrin police had arrested 20 Serbian nationals, led by two Russians, who were preparing a 'coup' against the Montenegrin government and (then) Prime Minister Djukanović. Although the government prosecutor was not very convincing in trying to connect the alleged plotters with the leaders of the (then united bloc of) Montenegrin opposition, who lost the election by only one parliamentary seat and unanimously claimed that the story of the 'coup' was fabricated by the Djukanovć government in order to create confusion among voters, and secure its hold on power (Tomovic, 2016), the event itself could easily have been taken as a 'notorious example' of Serbia's interference in Montenegrin domestic affairs. However, the government's hesitance to accuse official Serbia for involvement in the 'incident' (blaming instead 'criminal groups' from Russia, Serbia and Montenegro) ${ }^{20}$ and the assistance the Serbian government provided in deporting some suspects to Montenegro (Guardian, 2016a) seemed to have heralded (slightly) better days for the relationship between the two countries. Official relations between Serbia and Montenegro actually started to slightly improve several years ago after the governing coalition led by the Serbian Progressive Party (SPP) of (current) President Vučić came to power in Serbia in 2012 and after Djukanovic paid an official visit to Serbia in 2013, for the first time in ten years (Prime Minister's Office, 2013). ${ }^{21}$ Although some recent statements made by Djukanović have maintained that this improvement might be more cosmetic than real (Blic and Tanjug, 2018), it is hard to imagine that relations between these two countries could in the foreseeable future worsen beyond a 'normal level of tensions' so that they would pose a serious challenge for Serbia's accession.

\section{Bosnia and Herzegovina and Croatia}

While Serbia's relations with Montenegro during the last two decades could be described as 'traditionally problematic', but 'less dramatic' over the last years, it could be said that the level of drama in 'traditionally difficult' Serbia's relations with the

18 According to official results the Djukanović bloc got 55.5 per cent, only 0.5 per cent above the agreed threshold of 55 per cent for declaring independence. There were 210 complaints from the unionist opposition about the referendum process, all of which were quickly rejected by the EU appointed chairman of the referendum commission (Friis, 2007).

19 The conflict between the supporters of the Serbian Orthodox Church (which dominates the country's religious landscape), and the followers of the Montenegrin Orthodox Church (which was founded in 1993 and is still not canonically recognised) basically reflects and is rooted in the political conflict between the pro-Serb unionist opposition and the independent (or former 'separatist') ruling bloc (for more details see ESI, 2007; Zdravkovski and Morrison, 2014; Džankić, 2014).

20 Including also an ex-CIA officer (Guardian, 2018b).

21 However, many in the Serbian opposition, but also some independent analysts (see e.g. Ciric, 2018) claim that Serbian President Vučić sees a role model in Djukanovic's long-term rule over Montenegro and that he actually tries to copy Djukanovic's authoritarianism in Serbia. Nevertheless, according to Freedom House and TICI (see Table in the Introduction) both countries are (still) considered semi-consolidated democracies and are 'more democratised' than any of their Western Balkan neighbours. 
Croatian government and the Bosnia political leadership in Bosnia and Herzegovina has not declined, but rather increased since 2012. Moreover, it may be argued that relations between the Serbian and Croatian governments have deteriorated in the last few years and are the worst since the end of the Croatian war in 1995.

Most of the problems in Serbia's relations with Croatia and Bosnia and Herzegovina essentially derive from a different interpretation of the events that led to the collapse of the former Yugoslavia and the outbreak of ethnic conflicts and wars afterwards, as well as the outcomes of these wars. Problems in official relations between Serbia and Bosnia and Herzegovina are primarily caused by disputes and conflicts that exist in relations between political leaders of ethnic Bosniaks (or Bosnian Muslims) and Bosnian Serbs who fought on opposite sides during the B-H civil war 1992-1995 and who now live separated into two entities of the de facto confederative state. ${ }^{22}$ On the other hand, the core issue in political relations between modern day Serbia and Croatia relates to different and mutually disputed interpretations of the responsibility of their respective governments for both the breakout of the Croatian war (1991-1995) ${ }^{23}$ and the handling of the outcomes and legacies of this war.

Hence, a cooling of relations between Serbia (including the Bosnian Serbs in Republika Srpska) and the Bosniak political leadership in Bosnia-Herzegovina and the political elite in Croatia occurs each year, on the anniversary of two events which occurred during the Croatian and Bosnian civil wars (within a period of less than three weeks). The first of these was the mass killing of seven to eight thousand imprisoned Bosniak men and boys and the expulsion of more than 20,000 civilians from the Srebrenica region in east Bosnia by Bosnian Serb military and paramilitary forces in mid-July 1995, later defined by the International Court of Justice in Paris as "acts of genocide." (ICJ, 2007, p. 127). The second event relates to the offensive of the Croatian army (known as "Operation Storm") in early August 1995 against rebel ethnic Serbs during which some 200,000 Serb civilians left their homes in the Krajina region to be displaced as refugees in Serbia or in a much smaller number in the Republika Srpska's part of Bosnia-Herzegovina. While Serbian politicians in Serbia and particularly Republika Srpska continue to irritate their Bosniak counterparts by recognising the "horrible crime" but not the "genocidal character" of the Srebrenica massacre (see e.g. VOA News, 2015 and Reuters, 2015) the official Croatian celebration of Operation Storm as a public holiday ('Victory Day') on 5 August each year is perceived in Serbia, and particularly by official Serbian politicians and refugees from Croatia, as a cynical celebration of Croatia's 'ethnic cleansing'. In recent years, relations between the ruling political elites in Serbia and their two neighbours in the west particularly worsened during the ceremonies marking the 2oth anniversary of both events in 2015. The highly fraught relations between Serbia and the Bosniak leadership reached their lowest point after Russia (at Serbia's request) vetoed the British proposal for a UN resolution defining the Srebrenica massacre as a "genocide" in early July and then just a few days later the Serbian Prime Minister Vučić was attacked by the crowd while attending the

\footnotetext{
${ }^{22}$ After the war was terminated by the Dayton Peace Accords of November 1995 (which were formally signed as 'The General Framework Agreement for Peace in Bosnia and Herzegovina' in Paris on 14 December 1995) Bosnia and Herzegovina was established as a de facto confederative state consisting of two semi-independent entities - the 'Republika Srpska (RS)' and 'the Federation of Bosnia and Herzegovina' (i.e. the Bosniak-Croat entity) - with a feeble (con)federal Bosnian-Herzegovinian government (the agreement is available in full at http://peacemaker.un.org/sites/peacemaker.un.org/files/BA_951121_DaytonAgreement.pdf).

${ }^{23}$ This was the war that the Croatian police (and later army) waged against the remnants of the Yugoslav federal army and the rebelling Croatian Serbs in the early 1990 s which ended in August 1995 by so-called 'Operation Storm' in early August 1995 (see below).
} 
Srebrenica anniversary ceremony. ${ }^{24}$ However, while relations between the Vučić government in Belgrade and the Bosniak political leadership returned to normal (or "its usual level of difficulty") during the visit of the B-H Presidency to Belgrade on 23 July that same year, Serbo-Croatian relations had begun to go from bad to worse even before the 2015 celebration of 5 August (see e.g. Mikelic, 2015; B92net, 2015 and B92net/Tanjug, 2015) and have continued in the same direction to the present day.

Having never been more than 'moderately controversial', official relations between the Serbian and Croatian governments started to significantly deteriorate after the 2012 Serbian parliamentary and presidential elections which were won by the reformed and "Europeanised" former nationalist allies of the Serbian post-communist dictator Milosević. After former President Tadić had succeeded alongside his Croatian counterpart Josipović to significantly improve (or at least normalise) relations between the two countries during his second mandate (2008-2012), his successors President Nikolić (2012-2017) and his party deputy and the country President since 2017 Aleksndar Vučić from the Serbian Progressive Party (SPP) 25 struggled to build relations and gain trust from both President Josipović and the centre-left Croatian government of Prime Minister Milanović. Nothing changed when Josipovic was replaced by president Grabar-Kitarović after the Croatian presidential election in 2015, but bilateral relations between the two largest post-Yugoslav states worsened further after the centre-right HDZ of President Grabar-Kitarovic won the extraordinary parliamentary election in September 2016 and the coalition government was formed the following month. The Plenkovic government, which is still in power (September 2018), has continued to tolerate (and sometimes support) the nationalistic rhetoric and activities of various groups and individuals who have glorified (particularly during some public events, anniversaries and commemorations) the victorious 'Domovinski rat' (Homeland War) ${ }^{26}$ of the early 1990 s and "Operation Storm", while at the same time denouncing allegations of historical revisionism and injustice related to the fascist Ustasha movement and Croatia's Nazi puppet regime during the Second World War. Croatian Serbs (and even more so those who left in 1995) and the Serbian political and wider public were particularly irritated when in November 2016, the slogan of the Ustasha movement, 'Za dom spremni' ['For the Homeland ready'] was inscribed on a plaque near the Jasenovac concentration camp in which tens of thousands Serbs were killed during WWII, ${ }^{27}$ without a resolute condemnation by the Croatian government which needed ten months to remove the plaque (Mikelic, 2017a and 2017b). On the other hand, some high ranking politicians and media commentators in Serbia, particularly the leader of the oppositional Serbian Radical Party, Šešelj, who was convicted by the International Court in The Hague for war crimes (mainly committed against Croatian civilians), and the country's Minister of Defence, Vulin, have tried very hard to 'keep pace' with rising nationalism and anti-Serbism in Croatia. On many occasions since he was released from the Hague Tribunal in early 2015, Šešelj has been 'successful' in widely publicising 'his hatred' of the modern Croatian state which he

\footnotetext{
${ }^{24}$ When he came to pay tribute to the victims and "condemn this horrible crime" (BBCNews, 2015b).

${ }^{25}$ It was created as a national, centre-right and pro-EU(ropean) party by these two politicians in 2008, after they left the ultranationalist Serbian Radical Party of (then) the ICTY indictee Vojislav Šešelj.

${ }^{26}$ The phrase used in Croatia for the 1991-1995 war.

${ }^{27}$ According to official (communist) Yugoslav figures (supported by some Serbian authors) over 700,ooo people, mostly Serbs, were killed in this Ustasha concentration camp. However, more recent serious studies agree that more realistic figures are much lower, but still significant and they refer to between 83,000 and 100,000 victims of the Jasenovac camp, of which there were 50 to 60,000 Serbs (Zerjavić, 1989; Pavlowitch, 2008).
} 
identifies with the WWII Ustasha regime, ${ }^{28}$ whereas Minister Vulin has also issued similar statements and made other provocations towards the Croatian government for which he was banned from coming to Jasenovac in April 2018 to pay tribute to the victims of Ustasha's terror. Vulin commented that the ban was a 'provocation' and stated that ' $\mathrm{t}]$ he most horrible truth about Jasenovac is not only what happened there, but the fact that Croatia today will not show remorse for what it had done' (HINA, 2018). ${ }^{29}$ The Serbian government's decision to reciprocally declare Croatia's Minister of Defence a persona non grata in Serbia was another contributory factor to the deterioration of the relationship between the two countries, as were several bitter diplomatic notes exchanged regarding these (and some other) incidents over the last few years (see e.g. Rudic, 2018). Although the Croatian political leadership eventually decided not to recall their ambassador in Belgrade after the reciprocal bans against the two defence ministers $(\mathrm{N} 1,2018)$, current relations between the two countries can hardly be considered any better than in 2015 when Croatia indeed recalled their ambassador in Belgrade (after Šešelj publicly set on fire the Croatian flag).

\section{What problems do Serbia's relations with its neighbours pose for its accession?}

As discussed in the two previous sections, Serbia's relations (or non-relations) with Kosovo have been declared crucial for the successful completion of its accession to the EU and they are as such incorporated into one of the 35 accession negotiation chapters (number 35 - 'other issues') which must be successfully completed, i.e. 'closed' before Serbia can be declared ready to join the EU. Although the two sides still have numerous problems to resolve and are quite far away from a final deal, recent progress in narrowing the gap regarding the content of the 'binding agreement', combined with their mutually strong interest to reach an acceptable 'compromise' may in fact make the 'Kosovo knot' less of a problem for Serbia's accession than the (at first sight more trivial) issues that it has with other neighbours. Indeed, Serbia's relations with its three neighbours to the west, primarily Croatia, are also 'rich' with many problems that might create obstacles on Serbia's path to EU membership.

While Serbia's relations with Montenegro and the Bosniak political leadership in B-H have in general been problematic since the establishment of these two states in 2006 and 1995, respectively, there is not much evidence of a significant decline over the years. Moreover, as referred to in Section 2, Serbia's official relations with Montenegro have even shown some (very modest) signs of improvement in recent years. On the other hand, after they reached their lowest point in early July 2015 with regards to both the failed British proposal for a UN resolution on the 'Srebrenica genocide' and an attack on the Serbian president by the crowd while he was attending the Srebrenica anniversary ceremony a few days later, relations between the Serbian government and the Bosniak politicians are once again no more more problematic than usual. Although the president of Republika Srpska, Dodik has on many occasions annoyed the Bosniak

\footnotetext{
${ }^{28}$ Among these particularly offensive were two occasions when he burned the Croatian national flag at public places in Belgrade in April and August 2015 (Poznatov, 2015 and B92net, 2015) and his insult against the Croatian parliamentary delegation when he during an official visit to Serbia's Parliamentarians trampled the Croatian flag in the Serbian Parliamentary building in May 2018 (Rudic, 2018a).

${ }^{29}$ On another occasion, after President Grabar-Kitarović awarded the medals to the two retired Croatian generals who had been charged (but finally acquitted) by the International Court in The Hague with war crimes against Serbs during Operation Storm at the 2018 celebration of the anniversary of the event, Vulin stated: 'Croatia has a problem with common sense, and not with Serbia' (B92/Tanjug, 2018b).
} 
leadership with his statements on unsustainability of present B-H and the desire of Bosnian Serbs to secede from this country (and join Serbia) as soon as the 'international factors allow' (Inserbia.info., 2015; Srpska Times, 2018), Dodik's rhetoric and even some of his concrete actions in this regard $\mathrm{d}^{30}$ have so far marginally affected both the B-H political status quo established by the Dayton agreement and relations between the Serbian government and the Bosniak leadership. Considering the existence of strong interests among political elites in both countries to maintain peace and attain progress in meeting the criteria for EU accession on one side, and the strong EU commitment to preserving 'Dayton Bosnia-Herzegovina', it is very hard to believe that Serbia's relations with B-H may deteriorate to a level where they would pose an issue in Serbia's accession negotiations. This seems to be further assured after the EU launched the so-called 'Berlin process' in 2014 which focused on 'a broad reform agenda,' rather than constitutional changes in B-H (Juncos and Withman, 2015) and has already shown some signs of (slightly) improving cooperation among the political leaders of all three ethnic groups at all levels of government. ${ }^{31}$ However, the same cannot be said for the significant increase in political 'incidents' between the governing political elites in Serbia and Croatia over the last several years, which, combined with the fact that Croatia as an EU member has the power to bloc (or at least obstruct) progress in Serbia's accession negotiations, may become a serious hurdle for the latter's accession ambitions.

After it seemed that tensions between the two countries had (to some extent) calmed in early February 2015, when the International Court of Justice dismissed their respective claims of genocide committed during the war in the 1990s (BBC News, 2015a), only a few weeks later the Croatian delegation to the European Parliament attempted to prevent the adoption of the resolution on the opening of accession negotiations with Serbia. Although Croatia's amendment that Serbia change the country's law on the prosecution of war criminals and stop prosecuting its non-citizens according to this law before it would be allowed to open the first accession chapters was criticised by the representatives of the European Commission, and was rejected (in its original form) by the Parliament (EuroActive, 2015), in Serbia it was perceived as a direct obstruction of Serbia's accession bid. However, the Croatian government and its representatives in EU institutions have continued to insist that this and other

\footnotetext{
30 Particularly provocative was the organisation of a referendum in September 2017 regarding the viability of the Bosnia and Hercegovina's Constitutional Court's ban of the celebration of the $9^{\text {th }}$ January as a national holiday in Republica Srpska due to negative associations which it may raise among the non-Serbian/Christian Orthodox residents of RS (as 9 January is also a Serbian Orthodox religious holiday and the day on which RS was established in 1992 may raise). Although the same Court also banned the referendum from taking place and despite the strong objections of the Bosniak and (Western) international communities who feared that this referendum would be just a precursor to a referendum on the independence of RS, the referendum was held and 99 per cent of those who cast their votes (some 56 per cent of total RS population) supported the Republika Srpska authorities in rejecting the BH Constitutional Court's denunciation of the 9 January holiday (Deutsche Welle, 2016; BBCNews, 2016). However, nothing has substantially changed since then. The Republika Srpska authorities have continued to celebrate the $9^{\text {th }}$ of January as they used to (though without the presence of the special guard of the B-H Army which has been replaced with the special guard of the RS police - see e.g. Radio Free Europe, 2018), and to occasionally have harsh rhetorical exchanges with the Bosniak political leadership (MacDowal, 2017). Yet all the federal B-H institutions and the institutions of the two entities have continued to work as they had before this referendum and there have not been any official calls for a referendum on the independence of RS either.

31 After the EU council initiated in December 2014 (EU Foreign Affairs Council, 2014) a focus on the solution of the "outstanding socio-economic challenges[Bosnia and Herzegovina] faces" (European Commission 2015, p. 4) instead of changes to its constitutional order which the EU unsuccessfully insisted on for years (but was strongly opposed by Bosnian Serbs and Croats) the "Reform Agenda for Bosnia and Herzegovina 2015 - 2018" and some common reform actions by all three levels of the government of B-H were adopted already in July 2015 (Delegation of the European Union..., 2015, see also Petrovic, 2017).
} 
'open issues' in bilateral relations between the two countries ${ }^{32}$ ought to influence Serbia's progress in accession, even after Serbia was 'allowed' to open its first two accession negotiations chapters in December of the same year.

In early April 2016, an EU Council working group decided against debating Serbia's opening of accession Chapters 23 and 24 (dealing with the rule of law, the judiciary and human rights) from its agenda after Croatia failed to agree to it for the same reasons (listed above) which it used to object the adoption of the European parliament resolution in March 2015 (Euractiv, 12 April 2016). Then in December the same year Croatia blocked the opening of chapter 26 (on education and culture) over issues related to the Croat minority in Serbia and the return of cultural goods (Zaba, 2016). While Croatia (pressured by more influential EU members) later agreed that all these problematic chapters could be opened, ${ }^{33}$ at the time of writing, nearly three years after the EU opened the first accession negotiation chapters with Serbia, it is obvious that these negotiations will not be supported nor assisted by the governing political elite in Croatia. Therefore, the words of President Josipović, spoken when Croatia became an EU member on 1 July 2013, that Croatia 'hope[s and will assist] its neighbours [to] also complete this journey, as quickly as possible' (Pavelić, 2013), and repeated on many occasions by his successor President Grabar Kitarović and by Croatian Prime ministers, can only be considered 'polite rhetoric' in the context of Serbia's EU accession.

This, however, is not surprising considering the extensive issues in relations between the two countries discussed in the previous section. The above elaborated examples of Croatia's actions to block progress in Serbia's accession negotiations, taken together with the previous experience of Croatia and of some other EU member states in dealing with disputes with neighbours (Geddes and Taylor, 2016) particularly the ongoing border dispute between Croatia and Slovenia, ${ }^{34}$ signals that Croatia may pose a serious obstacle for Serbia's accession. While it is hard to believe that Croatia would be able to copy the Greek pattern regarding Macedonia's accession, ${ }^{35}$ it would definitely be able to significantly slow down and delay many administrative procedures and processes related to the accession negotiation process. If they want their country to continue progressing in the EU accession process, it seems that Serbian political leaders will need to take the 'Croatian factor' more seriously, particularly when trying to maintain a 'tough stance' and send 'strong messages' to their Croatian counterparts on any single issue and 'opportunity' that arises.

\section{Conclusions}

While the improvement or, more precisely, establishment of official relations with Kosovo via the signing of the 'binding agreement' remains the key pre-condition for the successful completion of Serbia's accession negotiations, its perpetually difficult

\footnotetext{
${ }^{32}$ From the 'precise identification' of all undentified Croats among 2,000 missing persons from the 1990s war, and the treatment of the Croatian ethnic minority in Serbia, to the disputed property and international borders between the two countries along the Danube river (see e.g. Dinić, 2015 and Kmezić, 2016).

${ }^{33}$ Chapters 23 and 24 were opened on 18 July, and chapter 26 was opened together with chapter 20 on 26 February 2017 (see EU Commission web site, 2018)

${ }^{34}$ After years of unsuccessful attempts to find a compromise solution for its border disputes in the Adriatic Sea, Slovenia and Croatia agreed to accept the international arbitration. However after the Permanent Court of Arbitration issued a binding ruling in June 2017, Croatia's authorities refused to implement it and continued the dispute with Slovenia (Vladisavljevic, 2018).

${ }^{35}$ Greece has, due to the 'name issue,' blocked any progress in Macedonia's accession to the EU for nearly 14 years (for more detail see Geddes and Taylor, 2016; Petrovic, 2017).
} 
relations with the Djukanovic governments in Montenegro, the Bosniak political leaders in Bosnia and Herzegovina and Croatia's political elite may also pose serious problems for its bid to join the EU. Although the major causes of problems in Serbia's relations with these neighbours are grounded in domestic factors, mainly related to the legacies of the violent dissolution of the former Yugoslavia, the EU also bears a certain degree of responsibility, particularly for the persistent longevity of some of these problems. Especially damaging in this regard was the EU's policy of prioritising regional and national political stability (as it was understood and defined in related EU policy incentives and actions), rather than democratic standards in the respective countries. Instead of stabilising the domestic political scene, the EU's years long insistence on the centralisation of B-H's constitution (which had zero chance of being consensually adopted by all three major ethnic groups as required by this same constitution) and its persistent support of Djukanovic's (semi-)authoritarian rule in Montenegro have sharpened ethnic divisions in the former and cemented political tensions and intolerance in the latter. This, as well as the EU's inability to 'do something' about the increased right-wing nationalism (strongly related to antiSerbism) in Croatia and a deterioration of respect for democratic standards and the rule of law in Serbia itself in recent years (see the Introduction and Markovic's and Kovacevic's contributions to this volume) could not have helped overcoming problems in Serbia's relations with any of these countries.

On the other hand, the EU's pressure, together with strong commitment from its officials, particularly the High Representative Mogherini (who personally chairs the Brussels talks between the two presidents) and Commissioner Hahn, on both Serbia and Kosovo to try to find common ground has shown that the EU still can 'do something' if it really wants and if it is ready to consider 'the rational interests of domestic actors' (Börzel, 2018, p. 124). Despite all odds and the seriousness of the disputes and misunderstandings expressed at the Brussels talks as discussed in this paper, thanks to their strong mutual interests and strong EU support, the Serbian and Kosovo governments (or more precisely their presidents) have been able to come close to an agreement which would directly lead to a serious improvement of their relations. This seems to be the (only) formula for solving the 'regional disputes' that the EU has asked Serbia (and its Western Balkan neighbours) to solve 'as a matter of urgency', including those which Serbia has with Croatia and which may eventually appear to be more challenging for Serbia's accession than its 'arch problem' with Kosovo.

\section{Bibliography}

Barlovac, Bojana (2013) Kosovo, Serbia Liaison Officers to Start Work, Balkaninside, 13 February (available at: http://www.balkaninsight.com/en/article/kosovo-andserbia-liaison-officers-ready-to-start).

BBC News (2015a). UN court dismisses Croatia and Serbia genocide claims", 3 February (available at: http://www.bbc.com/news/world-europe-31104973).

BBC News (2015b). Srebrenica massacre anniversary: Crowds chase Serb PM away. 11 July (available at: http://www.bbc.com/news/world-europe-33491540).

BBC News (2016). Bosnian Serb referendum backs disputed 9 January holiday, 25 September (available at: https://www.bbc.com/news/world-europe-37465653). 
Bieber, Florian (2011). Building Impossible States? State-Building Strategies and EU membership in the Western Balkans. Europe-Asia Studies, 63 (10), pp. 1783-1802.

Bieber, Florian (2018). Patterns of Competitive Authoritarianism in the Western Balkans. East European Politics 34 (3), pp. 337-354.

Blic (2018). Patrijarh Irinej: Kosovo je nas Jerusalim [Patriarch Irinej: Kosovo is our Jerusalem]. 20.08.2018 (available at: https://www.blic.rs/vesti/drustvo/patrijarhirinej-kosovo-je-nas-jerusalim/hptnllc).

Blic/Tanjug, Đukanović kritikovao zvanični Beograd i patrijarha Irineja: Nova medijsko-politička ofanziva iz Srbije [Djukanovic criticized official Belgrade and Patriarch Irinej: New media-political offensive from Serbia], 13/09/2018 (available at: https://www.blic.rs/vesti/politika/djukanovic-kritikovao-zvanicni-beograd-ipatrijarha-irineja-nova-medijsko-politicka/npwkq53).

Börzel, Tanja A. and Sonja Grimm (2018). Building Good (Enough) Governance in Postconflict Societies \& Areas of Limited Statehood: The European Union \& the Western Balkans. Daedalus. 147 (1), pp. 116-127

B92net (2015). Seselj once again sets Croatian flags on fire. August 6 (available at: http://www.b92.net/eng/news/politics.php?yyyy=2015\&mm=08\&dd=06\&nav_id=9 5002.)

B92net (2018). Vucic: There is no easy solution, Serbia has two paths. o7 August 2018 (available at: https://www.b92.net/eng/news/politics.php?yyyy=2018\&mm=08\&dd$=07 \&$ nav_id=104803.)

B92net/Tanjug (2015). Serbia's demarche to Croatia over incidents in Knin. August 6 (available at: https://www.b92.net/eng/news/politics.php?yyyy=2015\&mm =08\&dd$=$ o6\&nav_id=95014.)

B92net/Tanjug (2018a). Serbia without Kosovo unimaginable; Pope won't visit yet. 4 January 9avaiable at: https://www.b92.net/eng/news/politics.php?yyyy=2018\&mm=01\&dd=04\&nav_id=103193.).

B92net/Tanjug (2018b). Hrvatska ima problem sa zdravim razumom, a ne sa Srbijom [Croatia has a problem with common sense, and not with Serbia]. 5.08.2018 (avaiable at: https://www.b92.net/info/vesti/index.php?yyyy=2018\&mm=08\&dd=05\&nav_category=11\&nav_id=1427248).

Canas, V. (2007). Independent Montenegro: Early Assessment and Prospects for Euro-Atlantic Integration. NATO Parliamentary Assembly, Brussels, 6 October (available at: https://www.esiweb.org/pdf/montenegro_NATO-Independent\%20Montenegro-early\%20assessment-spring2007.pdf).

Delegation of the European Union to Bosnia and Herzegovina (2015). Reform Agenda for Bosnia and Herzegovina 2015 - 2018 (available at http://europa.ba/wpcontent/uploads/2015/o9/Reform-Agenda-BiH.pdf). 
Deutsche Welle (2013). Montenegro's peculiar path to EU membership, 07.02.2013 (available at: https://www.dw.com/en/montenegros-peculiar-path-to-eumembership/a-16583842).

Deutsche Welle (2015). Kosovo top court finds parts of EU-sponsored deal with Serbia unconstitutional, 24.12.2015 (available at: https://www.dw.com/en/kosovo-topcourt-finds-parts-of-eu-sponsored-deal-with-serbia-unconstitutional/a-18937945).

Deutsche Welle (2016). Bosnian Serbs defy Sarajevo with referendum for a national holiday. 25.09.2016 (available at: https://www.dw.com/en/bosnian-serbs-defysarajevo-with-referendum-for-a-national-holiday/a-35885579).

Deutsche Welle (2018a). Montenegro's Milo Djukanovic: The eternal president, 14.04.2018 (available at: https://www.dw.com/en/montenegros-milo-djukanovicthe-eternal-president/a-43380806).

Deutsche Welle (2018b). Serbia: Aleksandar Vucic ready to 'protect peace' in north Kosovo. 04.08.2018 (available at: https://www.dw.com/en/serbia-aleksandar-vucicready-to-protect-peace-in-north-kosovo/a-44951658).

Dinić, Milan (2015). Serbia - Croatia relations: No way forward in sight, EUROPP, LSE (http://blogs.lse.ac.uk/lsee/2015/o3/17/serbia-croatia-relations-no-wayforward-in-sight/).

Džankić, Jelena (2014). Reconstructing the Meaning of Being. Montenegrin. Slavic Review. 73 (2), pp. 347-371.

Emini, Donika and Isidora Stakic (2018). Belgrade and Pristina: lost in normalisation? European Union Institute for Security Studies (EUISS), April (available at: https://www.iss.europa.eu/sites/default/files/EUISSFiles/Brief\%205\%20Belgrade\% 20and\%20Pristina.pdf).

European Commission (2014). Enlargement Strategy and Main Challenges 2014-15, COM (2014) 700 final, Brussels 8.10.2014.

European Commission (2017). President Jean-Claude Juncker's State of the Union Address 2017, Brussels, 13 September 2017 (available at: http://europa.eu/rapid/press-release_SPEECH-17-3165_en.htm).

European Commission (2018a). A credible enlargement perspective for and enhanced EU engagement with the Western Balkans, COM (2018) 65 final, Strasbourg, 6.2.2018.

European Commission (2018b). Serbia 2018 Report. COM (2018) 450 final, Strasbourg, 17.4.2018.

European Commission. (Various years), Annual reports on [each of] the Western Balkan states, Brussels.

EuroActive (2015). Croatian MEPs test their 'firepower' against candidate Serbia. 12 March (available at: http://www.euractiv.com/sections/enlargement/croatian-mepstest-their-firepower-against-candidate-serbia-312852). 
EU General Affairs Council, 2012. Council conclusions on Enlargement and the Stabilisation and Association Process, Brussels, 28 February.

EU Foreign Affairs Council (2014). Council conclusions on Bosnia and Herzegovina Luxembourg, 14 April.

Fakiolas, Efstathios T. and Nikolaos Tzifakis (2017). Establishing the Rule of Law in Kosovo and Bosnia and Herzegovina: The Contribution of the EU Civilian Missions. In Fish, Steven, M., Gill Graeme and Milenko Petrovic (eds.) A Quarter Century of PostCommunism Assesse. Palgrave Macmillan, pp. 187-216.

Friis, K. (2007). The Referendum in Montenegro: The EU's 'Postmodern Diplomacy. European Foreign Affairs Review. 12 (1), pp. 67-88.

Geddes, Andrew and Andrew Taylor (2016). Those Who Knock on Europe's Door Must Repent? Bilateral Border Disputes and EU Enlargement. Political Studies, 64(4), 930947.

Gotev, Georgi (2017). Belgrade seeks 'delimitation' for Serbs in Kosovo. Euractive/Reuter. Aug 15, 2017 (available at: https://www.euractiv.com/section/global-europe/news/belgrade-seeks-delimitation-for-serbs-in-kosovo/.)

Gotev Georgi and Maja Poznatov (2016). Tensions grow over Serbian accession talks. Euractive. 12 April (available at: http://www.euractiv.com/section/enlargement/news/tensions-grow-over-serbias-accession-talks/)

Guardian (2016). Serbia deports Russians suspected of plotting Montenegro coup. 11 November (available at: https://www.theguardian.com/world/2016/nov/11/serbiadeports-russians-suspected-of-plotting-montenegro-coup).

Guardian (2018a). Kosovo detains Serbian politician after 'illegal entry' into region. 26 March (available at: https://www.theguardian.com/world/2018/mar/26/kosovoserbia-politician-marko-djuric)

Guardian (2018b). Ex-CIA officer faces arrest over alleged Montenegro coup plot. 12 August (available at: https://www.theguardian.com/world/2018/aug/12/ex-ciaofficer-faces-arrest-over-alleged-montenegro-coup-plot)

HINA (2018). Vulin Calls Croatia's Ban a 'Provocation'. 22 April (available at: https://www.total-croatia-news.com/politics/27688-vulin-calls-croatia-s-ban-aprovocation).

Hopkins, Valerie (2012). Montenegro: mafia state in the EU neighbourhood. Open Democracy. 5 July (available at:http://www.opendemocracy.net/valeriehopkins/montenegro-mafia-state-in-euneighbourhood)

ICJ (International Court of Justice, (2015). Application of the Convention on the Prevention and Punishment of the Crime of Genocide (Bosnia-Herzegovina v. Serbia and Montenegro) [2007] Judgment, General List No. 91, p. 127 (available at: http://www.icj-cij.org/docket/files/91/13685.pdf). 
Inserbia.info. (2015). Dodik: EU membership might not be the best path for $\mathrm{BiH}$. Inserbia.info, 19 November (available at http://inserbia.info/today/2015/11/dodikeu- membership-might-not-be-the-best-path-for-bih/).

International Crisis Group (2013). The Kosovo-Serbia Agreement: Why less is more (available at: http://blog.crisisgroup.org/europe-central-asia/2013/05/07/thekosovo-serbia-agreement-why-less-is-more/.

Juncos, Anna and Richard Whitman (2015). Europe as a Regional Actor: Neighbourhood Lost. Journal of Common Market Studies. 53 (S1), 200-215.

Kmezić, Marko (2016). Croatia's blocking of Serbia's EU integration: Another case of bilateral conditionality in the Balkans, EUROPP, LSE, 2016 (available at: http://bit.ly/1TViHQI).

Knaus, G. and M. Cox. (2004). Bosnia and Herzegovina: Europeanisation by decree. In J. Batt (ed.) The Western Balkans: moving on, Chaillot Paper. No. 70, Paris: Institute for Security Studies, 55-68.

Massari, Maurizio (2005). Do All Roads Lead to Brussels? Analysis of the Different Trajectories of Croatia, Serbia-Montenegro and Bosnia-Herzegovina. Cambridge Review of International Affairs. 18 (2), 259-273.

MacDowal, Andrew (2017). Bosnia's Serb Republic leader: No breakaway vote next year, but Bosnia-Herzegovina is a 'failing state'..., Politico Europe. 6/29/2017 (available at: https://www.politico.eu/article/milorad-dodik-bosnia-serb-republicserbia-leader-no-breakaway-vote-next-year).

Mikelic, Sven (2015). Croats Chant Anti-Serb Slogans at Nationalist Concert. BalkanInsight. 6 August (available at: http://www.balkaninsight.com/en/article/croats-chant-anti-serb-slogans-at-nationalist-concert-08-06-2015).

Mikelic, Sven (2017a). Rival Events Commemorate Croatian WWII Camp Victims. BalkanInsight. 24 April (available at: http://www.balkaninsight.com/en/article/again-multiple-commemorations-at-croatian-wwii-camp-jasenovac-04-242017).

Mikelic, Sven (2017b). Croatia Removes Fascist Slogan Plaque from Jasenovac. BalkanInsight. 9 July (available at: http://www.balkaninsight.com/en/article/croatian-wwii-fascist-chant-plaque-from-jasenovac-09-07-2017/1431/6).

Noutcheva, Gergana (2012). European Foreign Policy and the Challenges of Balkan Accession: Conditionality, Legitimacy and Compliance. London: Routledge.

N1 (2018). Croatia decides not to recall ambassador from Belgrade. 02.05.2018 (available at: http://hr.n1info.com/a299046/English/NEWS/Croatia-decides-not-torecall-ambassador-from-Belgrade.html).

Pavelić, Boris (2013). Croatia Vows to Bring Balkans Closer to EU, BalkanInsight. 2 July (available at: http://www.balkaninsight.com/en/article/presidents-of-theregion-form-a-group). 
Pavlowitch, Stevan, K., (2008). Hitlers New Disorder. The Second World War in Yugoslavia, New York: Columbia University Press.

Petrovic, Milenko (2013). The Democratic Transition of Post-Communist Europe - In the Shadow of communist differences and an uneven Europeanisation. Houndmills, Basingstoke: Palgrave Macmillan.

Petrovic, Milenko (2017). Post-Communist Transition under the Umbrella of Uneven Europeanisation: East Central Europe, the Baltic States and the Balkans. In Fish, Steven, M., Gill, Graeme and Milenko Petrovic (eds.). A Quarter Century of PostCommunism Assessed. Palgrave Macmillan, pp. 41-74.

Politico (2018). Serbia, Kosovo presidents broach border changes for historic deal. 25 August (available at: https://www.politico.eu/article/aleksandar-vucic-hashim-thaciserbia-kosovo-balkans-eu-enlargement-alpbach-forum/).

Pomorska, Karolina and Gergana Noutcheva (2017). Europe as a Regional Actor: Waning Influence in an Unstable and Authoritarian Neighbourhood, Journal of Common Market Studies. 55, 165-176.

Poznatov, Maja (2015). Hague court heightens tensions between Serbia and Croatia. Euractive. 3 April (available at: http://www.euractiv.com/sections/enlargement/hague-court-heightens-tensions-between-serbia-and-croatia-313529).

Prime Minister's Office (2013). Prime Minister Milo Đukanović in first official visit to Serbia since restoration of independence, 09.12.2013 (available at: http://www.predsjednik.gov.me/en/news/133765/Prime-Minister-Milo-dukanovicin-first-official-visit-to-Serbia-since-restoration-of-independence.html).

Radio Free Europe (2017). Serbia Outraged by French Court's Refusal To Extradite ExKosovo PM Haradinaj, April 27 (available at: https://www.rferl.org/a/kosovoharadinaj-released/28454651.html).

Radio Free Europe (2018). Defying Court Ban, Republika Srpska Goes Ahead With 'Statehood Day. o9 January, 2018 (available at: https://www.rferl.org/a/republikasrpska-statehood-day-defying-court-ban/28964699.html).

Rettman, Andrew (2018). EU eyes Kosovo and Serbia enlargement deal. Euobserver. 1 September (avaiable at: https://euobserver.com/enlargement/142709).

Reuters (2015). Bosnian Serb leader: Srebrenica was 2oth century's 'greatest deception. June 25, 2015 (available at: https://www.reuters.com/article/us-bosniaserbia-arrest/bosnian-serb-leader-srebrenica-was-20th-centurys-greatest-deceptionidUSKBNoP51OL20150625).

Rudic, Filip (2018). Timeline: Serbia-Croatia incidents keep revolving around past. BalkanInsight. 20 April (available at: http://www.balkaninsight.com/en/article/timeline-serbia-croatia-incidents-keep-revolving-around-past-04-19-2018).

Rudic, Filip (2018a). Croatian MPs Leave Serbia After Seselj Tramples Flag, BalkanInsight.18 April (available at: http://www.balkaninsight.com/en- 
/article/croatian-parliamentary-delegation-leaves-serbia-after-seselj-incident-04-182018).

Rudic, Filip (2018b). Vucic Claims Kosovo Won't Set Up Serb Municipality Association. BalkanInsight. 3 August (available at: http://www.balkaninsight.com/en/article/vucic-asks-kfor-to-prevent-infrastructure-objects-takeover-o8-o32018).

Srpska Times (2018). Dodik: People's right to self-determination should be. June 03, (available at: http://thesrpskatimes.com/dodik-peoples-right-to-self-determinationshould-be/).

Telegraf, (2018). Two Serbs helped terrorists in kidnapping Djuric and they will answer for that: Vucic addressed the nation. March 27 (available at: https://www.telegraf.rs/english/2946163-two-serbs-helped-terrorists-inkidnapping-djuric-and-they-will-answer-for-that-vucic-addressed-the-nation-video).

Tzallas, Thimios (2018). Macedonia name dispute: problem solved? EUROPP. LSE, London (avaiable at: blogs.lse.ac.uk/europpblog/2018/06/20/macedonia-namedispute-problem-solved/).

Tomovic, Dusica (2016a). Old Doubts Cling to Montenegro's New Cabinet, BalkanInsight. 1 December 2016 (available at: http://www.balkaninsight.com/en/article/montenegro-s-new-government-same-old-politics-11-30-2016).

Tomovic, Dusica (2016). Montenegro Prosecussion Accused of Fabricating Russian Plot Claims. BalkanInsight, 7 November (available at: http://www.balkaninsight.com/en/article/montenegro-opposition-slates-prosecution-over-russian-plotclaims-11-07-2016).

Vachudova, Milada Anna (2014). "EU Leverage and National Interests in the Balkans: The Puzzles of Enlargement Ten Years On”. Journal of Common Market Studies. 52 (1), 122-38.

Viena.At. (2018). Bundeskanzler Kurz traf Praesidenten Vucic und Thaci in Wien [Chancellor Kurz met Presidents Vucic and Thaci in Vienna]. 26.08.2018 (available at: http://www.vienna.at/bundeskanzler-kurz-traf-praesidenten-vucic-und-thaci-inwien/5903086).

Vladisavljevic, Ana (2018). EU Stays Out of Croatia-Slovenia Border Dispute, Balkan Insight. 18 June (available at: http://www.balkaninsight.com/en/article/ek-remainsneutral-on-croatia-slovenia-border-arbitration-dispute-06-18-2018).

VOA News (2015). Serbian PM to Attend Srebrenica Anniversary Ceremonies. 7 July, 2015 (available at: http:/www.voanews.com/content/serbs-tell-un-srebrenicaresolution-would-widen-bosnia-divisions/2851980.html).

Walker, Shaun (2018). Now is chance for Kosovo deal, says Serbian president - but at what cost? Guardian. 26 April 2018 (available at: https://www.theguardian.com/world/2018/apr/26/now-chance-kosovo-deal-serbian-president-what-costaleksandar-vucic). 
Zdravkovski, A., Morrison, K. (2014). The Orthodox Churches of Macedonia and Montenegro: The Quest for Autocephaly. In: Ramet S.P. (eds) Religion and Politics in Post-Socialist Central and Southeastern Europe. Palgrave Studies in Religion, Politics, and Policy. Palgrave Macmillan, London, 240-262.

Zaba, Natalia (2016). Serbia Furious at Croatian Block on EU Negotiations. BalkanInsight. 13 December (available at: http://www.balkaninsight.com/en/article/serbian-croatian-relations-tighten-again-after-brussels-meeting-12-132016).

Žerjavić, Vladimir (1989). Gubici stanovništva Jugoslavije u drugom svjetskom ratu [Losses of population of Yugoslavia in the Second World War]. Zagreb: Jugoslavensko viktimološko društvo. 